\title{
Competition in the South African manufacturing sector: An empirical probe
}

\author{
G. Djolov * \\ University of Stellenbosch Business School, and \\ Socio-Economic Integration Unit, Statistics South Africa, Pretoria, 0001, South Africa \\ *To whom all correspondence should be addressed \\ george.djolov@usb.ac.za; georged@statssa.gov.za
}

\begin{abstract}
This paper empirically probes competition in the South African manufacturing sector using the latest published data on the industries of this sector released by the national statistical office. It is found that enterprise behaviour in this sector is governed by competition where the negativity between industry concentration and its linkages with output, employment, labour productivity, profit margins, rates of return, investment, and producer prices, has more to do with the limiting of rivalry between enterprises, as opposed to growing concentration promoting by itself poor economic performance. The findings are consistent with earlier investigations. From a managerial perspective, they suggest that while adaptive behaviour by enterprises through imitation or experimental actions is likely to lead to positive profitability, any resultant profit margins and rates of return are ultimately dependant on how successful or decisive enterprises are at innovating if they wish to grow their output, raise labour productivity, invest and employ more, as well as secure the demand-inducing prices commensurate with their innovative record. Thus the success of an enterprise rests on its ability to innovate.
\end{abstract}

\section{Introduction}

In 2012, Statistics South Africa (Stats SA) published the second edition of the Compendium of Industrial Statistics (CIS). The Compendium furnishes a large amount of data on the economic performance of the South African manufacturing sector, which makes it possible to examine competition in the industries making up the manufacturing sector. This is what the present study is about. By competition is meant rivalry among enterprises within and across industries to supply a product or to remove unwanted demand in a product (Stigler, 1957: 1-2). To recall, market and industry are terms synonymously identified and interchanged with each other, and the same convention will be followed here. Likewise the same will be done for the terms of firm and enterprise since they too are synonymously identified and interchanged with each other.

Competition at the market or industry level is commonly articulated in terms of its industrial - sometimes called business - concentration. This captures to what extent the share of output, sales, assets or employment of an industry falls in the hands of few enterprises (Stigler, 1964: 18). In this way, the level of concentration in an industry shows whether its market structure can be characterised by monopoly, oligopoly, monopolistic competition or perfect competition (Ertl \& McCarrell, 2002: 9). Stigler (1964: 20) notes that by practical convention the dividing line between what is few and many enterprises in an industry is taken as four, such that an industry with up to four enterprises is considered to be composed of few enterprises and an industry with more than four enterprises is considered to be composed of many enterprises.

To recall, by economic textbook convention, market structure denotes the competitive situation in which a firm operates. On this basis, Khemani and Shapiro (1993: 58-63) define monopoly as the situation with a single supplying enterprise in a market, oligopoly as the situation with a small number of supplying enterprises who are interdependent in their pricing and output decisions, monopolistic competition as the situation with a small number of supplying enterprises who are independent in their pricing and output decisions, and perfect competition as the situation with a large number of supplying enterprises who are disconnected from each other in their pricing and output decisions. Table 1 gives a summarised account of the market conditions characteristic of each of these market structures, shortened from a review by Andreosso and Jacobson (2005: 104-114). 
Table 1: Market structures and their market conditions

\begin{tabular}{|c|c|c|c|c|}
\hline & \multicolumn{4}{|c|}{ Market Structure } \\
\hline & Perfect Competition & Monopolistic competition & Oligopoly & Monopoly \\
\hline Concentration level & \multicolumn{2}{|c|}{$0 \% \leq \mathrm{G}<50 \%$} & $50 \% \leq \mathrm{G}<90 \%$ & $90 \% \leq \mathrm{G} \leq 100 \%$ \\
\hline \multirow{7}{*}{$\begin{array}{l}\text { Market conditions } \\
\text { faced by enterprises }\end{array}$} & Free entry & Free entry & Entry is restricted & Entry is restricted \\
\hline & $\begin{array}{l}\text { Complete product } \\
\text { information }\end{array}$ & $\begin{array}{l}\text { Complete product } \\
\text { information }\end{array}$ & $\begin{array}{l}\text { Incomplete product } \\
\text { information }\end{array}$ & $\begin{array}{l}\text { Incomplete product } \\
\text { information }\end{array}$ \\
\hline & No private collusion & No private collusion & Private collusion is possible & No private collusion \\
\hline & $\begin{array}{l}\text { Product variety is } \\
\text { missing }\end{array}$ & Product variety exists & Product variety is possible & $\begin{array}{l}\text { Product variety is limited } \\
\text { or missing }\end{array}$ \\
\hline & $\begin{array}{l}\text { Equal access to } \\
\text { production technologies }\end{array}$ & $\begin{array}{l}\text { Equal access to production } \\
\text { technologies }\end{array}$ & $\begin{array}{l}\text { Equal access to production } \\
\text { technologies is possible }\end{array}$ & $\begin{array}{l}\text { Unequal access to } \\
\text { production technologies }\end{array}$ \\
\hline & $\begin{array}{l}\text { Capital and labour are } \\
\text { immediately mobile }\end{array}$ & $\begin{array}{l}\text { Capital and labour are } \\
\text { immediately mobile }\end{array}$ & $\begin{array}{l}\text { Capital and labour are not } \\
\text { immediately mobile }\end{array}$ & $\begin{array}{l}\text { Capital and labour are } \\
\text { not immediately mobile }\end{array}$ \\
\hline & No market power & $\begin{array}{l}\text { Market power is } \\
\text { immediately contestable }\end{array}$ & $\begin{array}{l}\text { Immediate contestability of } \\
\text { market power is possible }\end{array}$ & $\begin{array}{l}\text { Market power is not } \\
\text { immediately contestable }\end{array}$ \\
\hline
\end{tabular}

The industrial concentration levels of each structure reported in Table 1, which are based on the levels of the Gini concentration index $(\mathrm{G})$, are those suggested by Reekie (1989: 48). On the one hand, a Gini concentration index with a value of zero implies no industrial concentration, which depicts the ideal market structure of perfect competition. On the other hand a Gini concentration index of one implies absolute concentration in the sense of a single firm occupying an industry, which depicts the market structure of monopoly. Being a grey area - in the sense of depicting perfect competition with product differentiation or variety - monopolistic competition shares the same level of concentration with perfect competition (Cabral, 2000: 92). This is because the longevity of this differentiation is limited.

The crux of the content in Table 1 is that from the traditional economic standpoint, monopoly and competition are inversely related, provided barriers to entry are present and innovative activity is retarded. If the latter two exist, the higher an industry's or market's concentration level is, the closer to monopoly it moves, and resultantly the less competitive it becomes.

Moreover, higher industry concentration levels are assumed to be encouraging of collusion among incumbent firms in the sense of making it easier for them to create a collective monopoly, which conversely reduces the degree of competition in an industry. In such a closed market environment, existing firms then become large and may abuse their market power as part of earning higher returns. To remind, market power is the ability of an enterprise to alter prices and competition itself (Lachmann, 1992: 29, 32).

A comprehensive review by Fedderke and Simbanegavi (2008: 147-180) of concentration studies done on the South African manufacturing sector over the last quarter century, shows two prominent things. Firstly, the level of concentration is high and increasing across a wide range of industries making up this sector. Secondly, the resultantly high or increasing concentration levels have been linked to persistently high or rising growth in producer prices and profit margins, in addition to lower or declining growth in: output, employment, labour productivity, investment (i.e. capital accumulation), and lastly industrial rates of return. Considering that the importance of studying industry concentration is at the heart of determining whether an industry or a sector of the economy is competitive, it appears appropriate to probe what the applicable case for the South African manufacturing sector is.

To this end, the available data in the Compendium of Industrial Statistics will be used. Critical to this enquiry will be exploring how barriers to entry interact with innovative activity. As outlined by Khemani and Shapiro (1993: 13, 49), (a) barriers to entry are obstacles induced by incumbent enterprises in their normal course of business, which prevent or deter the entry of new enterprises into an industry, and (b) innovative activity is the activity undertaken by an enterprise to move out of imitation and/or duplication.

\section{Barriers to entry and innovative activity}

There are three types of barriers to entry (West, 2007: 3-4), namely (a) absolute cost advantages, referring to the attainment of lower total costs of operation in relation to rivals; (b) economies of scale, referring to falling average costs of operation as output increases; and (c) product differentiation, referring to the absence of perfect product substitution between rivals.

Martins and Price (2004: 6-8) have proposed two distinct general classifications for manufacturing industries according to barriers to entry. The first classification is based on a combination of absolute cost advantages and economies of scale. To this end, they identify these advantages from each industry's set-up, i.e. sunk costs as belonging to the plants with economies of scale in the familiar sense that such plants have the lowest average cost of production.

The second classification is based on product differentiation. Here, Martins and Price (2004: 6-8) identify if such differentiation exists in terms of relative $R \& D$ intensity as measured by each industry's outlays of R\&D spending to its gross output. Martins and Price (2004: 7) note that this latter classification is in effect also a classification of innovative activity since (a) such activity is a prerequisite 
for product differentiation, and (b) $R \& D$ expenditure knowingly carries widespread technological spill-over effects. Table 2 gives a summary of the Martins-Price classifications after they are applied to all industries in the Compendium of Industrial Statistics.

\section{Table 2: Manufacturing industries classified by entry barriers and innovative activity}

\begin{tabular}{|c|c|c|c|}
\hline & & \multicolumn{2}{|c|}{ Innovative activity } \\
\hline & & Low & High \\
\hline \multirow[t]{2}{*}{ Barriers to entry } & Low & $\begin{array}{l}\text { Fabricated metal products } \\
\text { Food products } \\
\text { Footwear } \\
\text { Furniture and fixtures } \\
\text { Leather and fur } \\
\text { Non-metallic minerals } \\
\text { Paper and paper products } \\
\text { Plastics } \\
\text { Printing and publishing } \\
\text { Textiles } \\
\text { Wearing apparel } \\
\text { Wood products }\end{array}$ & $\begin{array}{l}\text { Non-electrical machinery } \\
\text { SciTech equipment } \\
\text { Recycling and refined assembly }\end{array}$ \\
\hline & High & $\begin{array}{l}\text { Beverages } \\
\text { Glass and glass products } \\
\text { Iron and steel } \\
\text { Non-ferrous metals } \\
\text { Rubber products } \\
\text { Tobacco }\end{array}$ & $\begin{array}{l}\text { Electrical machinery } \\
\text { Industrial chemicals } \\
\text { Petroleum and petrochemicals } \\
\text { Raw chemicals } \\
\text { Transport equipment }\end{array}$ \\
\hline
\end{tabular}

West (2007: 1-4) and Fagerberg (2009: 20-21) have provided simple but effective explanations as to why barriers to entry and innovative activity serve as predeterminants for the inverse relationship between monopoly and competition. As West (2007: 1, 4) points out, before an enterprise can compete in an industry, it has to be able to enter it. As such, entry barriers can retard, diminish, or entirely prevent the industry's usual mechanism for checking market power, which is the attraction and arrival of new enterprises. On the other hand as Fagerberg (2009: 20-21) highlights, in true Schumpeterian style, the arrival of the new enterprise or the creation of entry barriers by the incumbent enterprise, is completely dependent on their innovative activities to succeed with introducing: a new product, a new technology or method of production, a new source of supply in the form of a new input to production or the opening up of a new market, and lastly a new type of organization that compliments the implementation of either of these introductions. Resultantly different configurations between barriers to entry and innovative activity produce different market environments with understandably different concentration levels. To see this, Table 3 presents these environments after merging Table 1 with Table 2.

Table 3: Entry barriers and innovative activity by industry structure and concentration

\begin{tabular}{|c|c|c|c|}
\hline & & & \\
\hline & & Low & High \\
\hline \multirow{8}{*}{$\begin{array}{l}\text { Barriers } \\
\text { to entry }\end{array}$} & \multirow{4}{*}{ Low } & Perfect competition & Monopolistic competition \\
\hline & & OR & OR \\
\hline & & Oligopoly & Oligopoly \\
\hline & & $(0 \% \leq \mathrm{G}<90 \%)$ & $(0 \% \leq \mathrm{G}<90 \%)$ \\
\hline & \multirow{4}{*}{ High } & Oligopoly & Oligopoly \\
\hline & & OR & OR \\
\hline & & Monopoly & Monopoly \\
\hline & & $(50 \% \leq \mathrm{G} \leq 100 \%)$ & $(50 \% \leq \mathrm{G} \leq 100 \%)$ \\
\hline
\end{tabular}

One of the realizations to be gained from Table 3 is that unlike perfect competition and monopolistic competition, the market structures of oligopoly and monopoly are transient. They can occur either when barriers to entry are high and innovative activity is low, or alternatively when both of these are high. Examples of the former include parastatal-run industries where the licensed incumbent is the sole provider of a singular product relatively unchallenged by the need to innovate. Examples of the latter include closely contested industries where incoming or existing 
incumbents maintain or gain competitive position according to the innovations they bring to market. Which structure is applicable is dependent on the facts of each case under consideration.

On its own, oligopoly also arises when barriers to entry and innovative activity are low, as well as when this activity is high. The first of these oligopoly cases - also called Bertrand's paradox - is known to prevail with as few as two enterprises. This occurs when the industry in which they operate is unattractive to potential entrants because of the absence of entry barriers (Tirole, 1998: 210-211). The absence of these barriers is the very reason why the twofirm (i.e. duopoly) arrangement is capable of yielding a perfectly competitive market. The second oligopoly case occurs if innovative activity in the form of product differentiation is easy to imitate or duplicate soon after introduction.

The other realization offered by Table 3 is that it gives context to understanding the findings of high concentration levels in the South African manufacturing sector referred to earlier on. Such a picture points to the presence of an oligopolistic structure within and across industries that is defined by high barriers to entry and low innovative activity. It is in such a situation that the attraction or arrival of new competitors is held back, at the same time as is the lessening of the drive for innovative activity among incumbent enterprises, since the impetus for entry which would check the incumbent's market power is restrained. By implication, only when the manufacturing sector and its industries are affected in this way should the found negative consequences from high concentration be expected. But sticking to such explanation gives a monotonous picture of competition in the South African manufacturing sector, because it does not admit of the likely existence of the other possibilities sketched out in Table 2 .

For instance superior ability in lowering production costs or in improving products, be it the consequence of scale economies or absolute cost advantages, may well shift profits and sales from the unsuccessful to the successful and efficient firms (Reekie, 1991: 32). Thus high or rising concentration levels can be attributed to reasons totally disconnected from contrived scarcity or even unchecked market power. Such situations will move the manufacturing sector toward an oligopolistic or monopolising market structure that is characterised by high entry barriers in response to high innovative activity. New entrants or existing rivals within and across industries will emulate or improve upon the activities of the successful enterprises until the gains from doing so no longer exist. Then, shifts will take place to any of the other possible market environments, i.e. configurations.

To be clear, the gains are specific to the enterprises, which perform well in terms of productive efficiency, as being reflected in their absolute cost advantages and/or economies of scale, as well as in the innovations they bring in the form of the product differentiation they create. Other firms in the same industry will not share in these gains unless they are generated from the same sources. By analogy the same will hold across all industries. Thus, if firms increase in size they may be able to benefit from economies of scale, which is a cost advantage due to size. In this way when the firm becomes large it will have a lower cost per unit of output than a smaller firm, which should transmit into lower product prices. Such a beneficial outcome is likely to occur in industries characterised by high fixed costs and a greater scope of specialization in innovation.

By contrast, if the source of the gains is not to compete on productive efficiency or innovation - as will occur under enterprise arrangements in favour of collective monopoly or collusion - then the "competitive" impact on the likes of industry concentration, output, employment, labour productivity, profit margins, rates of return, investment, and producer prices will become uniform as the firms within any industry strive to collude. In such a situation, the impact on the market environment will be identical to that of high entry barriers and low innovative activity. This is because this is the market environment that collective monopoly creates. Kornai (1980: 152, 155) explains how. If such monopoly is created it allows its participating enterprises to fix a price for the product they make. This also enables them to increase product prices out of turn, without the corrective power of competition since only they can benefit from the price fixture. In this way the life of the participating enterprises and the life of the people working for them become more secure, since fear of any vital danger is removed. This in itself also induces an easy-going, minimalistic attitude to productivity. If the survival of each participating enterprise is automatically guaranteed, the personal responsibility of its employees is obscured, such that the incentives for productive efficiency and innovation become retarded or stunted. The enterprise becomes aware that neither its survival, nor even its growth, depends strictly on profitability. By extension, in implementing its investment decisions, the enterprise can go beyond the financial resources available currently or in the near future, without too much risk, as the loss will sooner or later be passed in the form of higher prices. On the one hand this will then lead to thoughtless investment decisions, and on the other hand to wasteful implementation, which again will harm efficiency. Hence, should incumbent or incoming enterprises aim to maintain or improve competitive position by forming collective monopolies as the means to "compete", the observance of an anti-competitive outcome within and across industries will be a matter of fact.

To test whether the above is the "competing" approach by enterprises in South Africa's manufacturing industries, the next section presents empirical findings from the available data in the Compendium of Industrial Statistics. That section also sheds light on the possible sources shaping competition in these industries. In respect of the empirical enquiry, the computed indicators are derived from the published Compendium data, which has annual coverage from 2003 through to 2010. The choice of computational techniques is predicated on the recommendation by Everitt and Dunn (1982: 45) to choose the simplest from those that are 
applicable to one's data, as this will ease the difficult task of interpreting the final results.

With this in mind, the computations are done along the following lines:

(a) Each industry's concentration level over the aforementioned time period is obtained as its geometric mean in order to capture the overall progression of these levels by minimising the influence of their outlying observations. Thereafter the concentration level of each market environment is obtained as the arithmetic average of these means.

(b) Output growth for each industry is firstly obtained as the compound annual growth rate from the indexed series of its value added in real terms. Afterwards these compound annual growth rates are arithmetically averaged to get the output growth of each market environment.

(c) The same averaging procedure for output growth is applied to obtain the series of: growth in investment, which stems from the compound annual growth rates of the indexed series of gross capital stock in real terms; growth in labour productivity, which stems from the compound annual growth rates of the labour productivity index; growth in employment, which stems from the compound annual growth rates of the indexed series of the number of employed; and lastly the growth in producer prices, which stems from the compound annual growth rates of the series for the Fisher price index.

(d) To recall, an industry's profit margin is estimated as the ratio of its gross operating profit - being the difference between its value added and labour remuneration - to its gross output, while an industry's rate of return is estimated as the ratio of its gross operating profit to its gross capital stock. These formulations are applied to the compound annual growth rates of the indexed realdenominated series of gross operating profit, labour remuneration, gross output, and gross capital stock, to obtain the growth series of each industry's profit margin and that of its rate of return. Then, these latter two series are averaged, to get the overall growth in profit margin and that of the rate of return for each market environment.

(e) Lastly, the yearly values for each indicator are obtained as the most probable maximum value the indicator is likely to assume. This is done by deriving the upper limits of their Chebyshev confidence intervals as applied on their averaged series. Chebyshev intervals are computed because in each case we are dealing with small sample sizes of fewer than thirty observations, in addition to not knowing in any case the applicable distribution of an indicator or for that matter its population's standard deviation or mean. The benefits from working with the yearly confidence interval estimates are twofold. Firstly, they give each indicator's most likely estimate that is attainable in the time period considered, thereby focusing attention on its most feasible value. Secondly, in one number, they incorporate the variability of the indicators' series by accounting for all their fluctuations over time, thus sharpening the focus of inspection to a single rather than several numbers. Using the standard convention for lack of precision at 5\%, the $95 \%$ one-sided Chebyshev confidence interval is calculated for all indicators, which depicts the most probable maximum value the indicators are likely to assume, on the average, in $95 \%$ of the time. To this end, the intervals are computed according to the procedure described in Salvatore (1982: 78). This involves adding to each indicator's averaged value its margin of error. The latter is obtained as the product between the constant of the coverage probability that will yield the one-sided $95 \%$ confidence level, which is 3.16 in the present instance, and the ratio of each indicator's standard deviation to the square root of the number of its participating observations.

\section{Empirical findings}

Table 4 presents the results of the numerical analysis with reference to the indicators' yearly values computed according to the outlined steps. It is clearly visible that if collective monopoly or collusion was indeed the dominant means by which enterprises seek to build their "competitive" positions, then the numerical picture in all market environments should be the same as that for highbarriers to entry and low innovative activity. But as the numbers are different, this is clearly not the case. By implication then, the source of enterprises creating competitive advantage between and within industries appears to be competition itself. It is precisely because of competition that the numerical outcomes of different market environments are not uniform.

The rivalry among enterprises between and within industries to supply a product or to remove unwanted demand in a product creates a commercial drive for allocative efficiency. As noted by Lachmann (1992: 25), and subsequently by Cabral (2000: 26-27, 159), such drive prompts enterprises to innovate and to create productive efficiency. The starting point is that some evidence in some industries shows the prospects for higher rates of return as opposed to this reachable in other industries, or indeed the industry in which the enterprise already operates in. This prompts a shift in investments away from those industries with lower rates of return to those with higher rates of return. This does not mean that the market environment with the better returns should be adopted at the expense of completely moving out of the market environment with less attractive returns. Instead both market environments can be operated in, if ways are found to minimize the relative differences in their rates of return. This is handled by not over-investing in the less rewarding market environment, and by not underinvesting in the more rewarding market environment. If however such discrepancy in investment does occur, then the response of enterprises is to shift resources out of the over-invested environment into the under-invested environment until in each case productive efficiency and innovation are allocated with minimal relative imbalance, 
i.e. without allocative inefficiency. Because such commercial acts are pursued by most if not all enterprises between and within industries, the ensuing competitive activity leads to different outcomes in different market environments, as evidenced by the figures in Table 4.

Table 4: Effects of competition in industries with different market environments (Yearly values, 2003-2010)

\begin{tabular}{|c|c|c|c|}
\hline & & \multicolumn{2}{|c|}{ Innovative activity } \\
\hline & & Low & High \\
\hline \multirow{16}{*}{$\begin{array}{l}\text { Barriers } \\
\text { to entry }\end{array}$} & \multirow{8}{*}{ Low } & $\begin{array}{c}\text { Concentration level } \\
77 \%\end{array}$ & $\begin{array}{c}\text { Concentration level } \\
79 \%\end{array}$ \\
\hline & & $\begin{array}{c}\text { Output growth } \\
2.5 \% \\
\end{array}$ & $\begin{array}{c}\text { Output growth } \\
7.4 \% \\
\end{array}$ \\
\hline & & $\begin{array}{c}\text { Employment growth } \\
1.8 \%\end{array}$ & $\begin{array}{c}\text { Employment growth } \\
3.9 \%\end{array}$ \\
\hline & & $\begin{array}{l}\text { Labour productivity growth } \\
5.7 \%\end{array}$ & $\begin{array}{l}\text { Labour productivity growth } \\
8.9 \%\end{array}$ \\
\hline & & $\begin{array}{c}\text { Growth in profit margins } \\
4.5 \%\end{array}$ & $\begin{array}{l}\text { Growth in profit margins } \\
4.0 \%\end{array}$ \\
\hline & & $\begin{array}{c}\text { Rate of return growth } \\
5.8 \%\end{array}$ & $\begin{array}{l}\text { Rate of return growth } \\
47.7 \%\end{array}$ \\
\hline & & $\begin{array}{c}\text { Investment growth } \\
0.2 \% \\
\end{array}$ & $\begin{array}{c}\text { Investment growth } \\
2.3 \% \\
\end{array}$ \\
\hline & & $\begin{array}{c}\text { Producer prices growth } \\
6.0 \%\end{array}$ & $\begin{array}{c}\text { Producer prices growth } \\
7.2 \% \\
\end{array}$ \\
\hline & \multirow{8}{*}{ High } & $\begin{array}{c}\text { Concentration level } \\
86 \%\end{array}$ & $\begin{array}{c}\text { Concentration level } \\
88 \%\end{array}$ \\
\hline & & $\begin{array}{c}\text { Output growth } \\
2.3 \% \\
\end{array}$ & $\begin{array}{c}\text { Output growth } \\
2.6 \% \\
\end{array}$ \\
\hline & & $\begin{array}{c}\text { Employment growth } \\
-1.2 \%\end{array}$ & $\begin{array}{c}\text { Employment growth } \\
2.9 \%\end{array}$ \\
\hline & & $\begin{array}{l}\text { Labour productivity growth } \\
4.8 \%\end{array}$ & $\begin{array}{l}\text { Labour productivity growth } \\
9.2 \%\end{array}$ \\
\hline & & $\begin{array}{l}\text { Growth in profit margins } \\
11.9 \%\end{array}$ & $\begin{array}{c}\text { Growth in profit margins } \\
13.9 \%\end{array}$ \\
\hline & & $\begin{array}{c}\text { Rate of return growth } \\
3.9 \%\end{array}$ & $\begin{array}{l}\text { Rate of return growth } \\
23.9 \%\end{array}$ \\
\hline & & $\begin{array}{c}\text { Investment growth } \\
0.6 \%\end{array}$ & $\begin{array}{c}\text { Investment growth } \\
2.8 \%\end{array}$ \\
\hline & & $\begin{array}{c}\text { Producer prices growth } \\
9.3 \%\end{array}$ & $\begin{array}{c}\text { Producer prices growth } \\
6.3 \%\end{array}$ \\
\hline
\end{tabular}

The sign illuminating the presence of allocative efficiency begins with the concentration levels of the different market environments. All concentration levels are in the oligopolistic range of between $77 \%$ and $88 \%$ of the Gini index, indicating that overall the manufacturing sector is characterised by an oligopolistic market structure irrespective of its market environment. This is seemingly innate since the next production process bringing best economies of scale will ultimately arise from enterprises competing to innovate in (a) product development, whether for inputs to production or final consumer products, (b) the opening up of previously inexistent markets, or (c) organizational function and form like the undertaking of unique mergers and acquisitions aimed at defining and redefining the nature and scope of their operations. The enterprise that discovers or adopts anyone or all of these innovations will gain absolute cost advantages relative to its rivals. As a consequence, a market environment with high barriers to entry and high innovative activity will walk handin-hand with higher concentration then if either barriers to entry or innovative activity were lower. The present concentration numbers bear this out.
Those industries with high innovative activity, which incidentally also promotes high barriers to entry, are able to support such activity subject to greater labour productivity. This is because more innovation demands more of skilled labour. Provided the uptake of this type of labour is without diminishing returns, increases in skilled labour will deliver closely similar increases in production. Thus the growths of output and employment in the market environment of both high barriers to entry and innovative activity will tend to follow each other closely. This is corroborated by their respective numbers of $2.6 \%$ and $2.9 \%$ per annum. More importantly, the higher absorption of skilled labour also explains why the same market environment experiences the highest growth in labour productivity of $9.2 \%$ per annum relative to the lesser innovative markets, where this productivity growth drops to between $4.8 \%$ and $5.7 \%$ per annum.

But innovation is a double-edged sword. While it confers gains in labour productivity, minor innovations - also known as imitations and duplications - from competing enterprises, will cut through profit margins and rates of 
return for everyone in the industry they are introduced in. Resultantly, for industries with highly innovative activity and high barriers to entry, growths in profit margin and rates of return drop respectively from $13.9 \%$ to $4.5 \%$ and from $23.9 \%$ to $5.8 \%$ per annum, to mirror the shift to a lessened innovative activity and lower barriers to entry, as more imitations and/or duplications arise. To get out of such a situation, enterprises have to make investments into new innovative activities to give them the next high barrier to entry, as well as to make it possible for them to extract the premium from such a move, which is embodied by an accelerated growth of producer prices. For the market environment with high entry barriers and high innovative activity this is corroborated by its higher positive growths of investment and producer prices, which at $2.8 \%$ and $6.3 \%$ per annum are correspondingly higher to the $0.2 \%$ and $6.0 \%$ per annum for the market environment with low innovative activity and low barriers to entry.

At $6.0 \%$ per annum, the extent of price increases in industries with low barriers to entry and low innovative activity is somewhat lower to the $6.3 \%$ per annum for the industries sharing high innovative activity and high barriers to entry. The reason for this lower growth in prices is attributable either to the slowdown or lack of innovative activity because it forces enterprises to make supplies of essentially the same or similar products thereby limiting the scope for price increases. Under such a situation, the annual growth of labour productivity of $5.7 \%$ per annum that is experienced by industries with low barriers to entry and low innovative activity does not come from higher growth in employment given that less of skilled labour will be needed, but more from the higher growth in the output of the same or similar products being produced. The discrepancy between employment and output growth for these industries, at $1.8 \%$ and $2.5 \%$ per annum respectively, confirms this.

On the other hand the rise in producer prices in industries with both high innovative activity and barriers to entry is delimited by any ensuing innovative activity. It is precisely because of such activity that highly innovative industries with higher barriers to entry have a relatively lower increase in producer prices, which also extends to those industries typified by lower innovation and higher barriers to entry. For the latter industries, the corresponding figure in the growth of producer prices is $9.3 \%$ per annum.

As to be anticipated, the market environment defined by high barriers to entry and low innovative activity produces the highest increases in producer prices, essentially due to its high barriers to entry. These barriers have the effect of delaying entry, and by so doing delaying competition from bringing price increases down. Because the persistence of these price increases is not due to innovative activity given that this activity is low or subdued, enterprises loose the incentive to outperform the output that enterprises in other industries churn out. This is reflected in the comparatively lower increases of output growth at $2.3 \%$ per annum relative to the other market environments where this growth is between $2.5 \%$ and $2.6 \%$ per annum, depending on whether the corresponding comparison is with respect to the market environment of low innovative activity and low barriers to entry or that of high barriers to entry and high innovative activity. This lack of incentive to perform better in production, especially in terms of innovative output, slows down the demand for skilled labour. This explains why the market environment of high barriers to entry and low innovative activity experiences a contraction in employment of $1.2 \%$ per annum.

This contraction in the uptake of employment coupled with the comparatively lower growth in output, leads to the slowest acceleration of labour productivity in the industries with low innovative activity and high barriers to entry compared to the other market environments. The findings also show a similar case for the market environment with jointly low innovative activity and barriers to entry because here enterprises will get to keep their presence only if their existing labour force can produce more of the same product.

A market environment with higher barriers to entry and lower innovative activity de facto resembles a closed market, in which as known incumbent enterprises have seemingly guaranteed yields because the threat of entry is weakened. Because of the relative market foreclosure, the motivation to innovate, which comes with entry, dissipates. Consequentially this leads to inefficient production with dated or outdated methods and processes. By chain reaction, the growth of investment also holds back. As explained earlier on, this is because in a closed or relatively closed market, enterprises have no incentive to compete for the benefit of improving supply. By contrast, as the present numbers show, in a relatively open market, i.e. this with lower barriers to entry and higher innovative activity, the unfolding situation is diametrically opposing. Growth of investment in the relatively closed market is $0.6 \%$ per annum but $2.3 \%$ per annum in the relatively open market. This conforms to expectations, as after all, industries closed from competition are shielded from entry, which does not compel them to innovate or to be productively efficient. By contrast such pressure cannot be avoided in the more open market environment. By corollary, low growth in investment essentially means that present as well as future market opportunities that could be efficiently or effectively exploited are foregone. Such dual loss from present and future opportunities hits the rate of return harder than the profit margin as the former is more intimately connected to the opportunity costs of an enterprise than the latter. By extension this would translate into a larger prospective decline in the growth of the rate of return to that of the profit margin. This conclusion is supported by the present results. For instance, at $3.9 \%$ per annum, the growth in the rate of return for the relatively closed market environment is noticeably smaller to the $47.7 \%$ per annum for the relatively open market environment, whereas the parallel difference from $11.9 \%$ to $4.0 \%$ per annum in the growth of their profit margins is substantially smaller.

There is more. The results suggest that the existence of market environments characterised by both low innovative activity and barriers to entry, or by low innovative activity and high barriers to entry, is a necessary condition firstly for 
activating allocative efficiency, and secondly for cultivating the search for productive efficiency. The industries of these market environments have the lowest growing rates of return. This will prompt the affected enterprises to look to other markets where this can redressed. The market with low barriers to entry and high innovative activity is an obvious choice because (a) access is open, meaning that entry is practically unrestricted, even if the price for entry is innovation, (b) its rates of return, as confirmed by their numbers in Table 4, are better given their endurance under intense rivalry, and (c) at least from the view of enterprises already coming from an environment of low barriers to entry, there is the prospect of higher producer prices for any output produced, as confirmed by the growth of producer prices, at $7.2 \%$ per annum, which is the highest outside that of the relatively closed market environment.

Motivated by the above, those enterprises wanting redress from the relatively more closed markets will enter the relatively more open markets. These entries will bring growth in investment, in addition to that already made by any incumbent enterprises, which will altogether push investment growth even higher. As the investments are in support of increased innovation, the copying of which by imitation or duplication is very probable due to low barriers to entry, the growth in investment will fall slightly short of what it could be were imitation and duplication more restricted as in the case of higher barriers to entry. This is why the market with high innovative activity and low barriers to entry experiences growth in investment at $2.3 \%$ per annum that is second only to the market with similarly high innovative activity but higher barriers to entry at $2.8 \%$ per annum.

Such investments in support of more innovation will give the enterprises that succeed in putting the resultant innovations to market, a position of relative monopoly. This accounts for why a relatively high concentration level of $79 \%$ is observed for the relatively open market. But to remind, this monopoly is relative, because other attempts at innovation motivated by this environment's promising rates of return, will have as their goal the introduction of imitations or duplications to the original product. This will weaken the initial monopolist's position. And if rivals pursue the marketing of these imitations or duplications vigorously, over-trading sets in, resulting in excessive production. In the present case, this is witnessed by the industries in the relatively open market environment having the highest growth in output, which at $7.4 \%$ per annum exceeds that of any other market environment. As the introduction of another innovative product, or indeed its imitation or duplication, is always possible, competition to meet demand for the same or similar products will spread. Vying for market position by means of bringing major or minor innovations to market, will demand that enterprises recruit skilled labour, albeit to different degrees. As part and parcel of this, together with an increased growth in production, employment growth in the relatively open market environment will also increase. The results show that this increase comes to $3.9 \%$ per annum. However because of excessive production in this environment, its employment growth will be comparatively lower, as happens to be the case. Consequentially a strong growth of labour productivity will occur in this environment. This growth will be reflective of the rivalry between enterprises to be in a continuous race to innovate. As the relatively easier copying of products will make the gains from innovation shorter in duration, the experienced growth in labour productivity will be slightly lower to that of the market with equally high innovative activity but higher barriers to entry. This is supported by the small difference in the growths of labour productivity between the two market environments, being $8.9 \%$ and $9.2 \%$ per annum respectively.

The foregoing concludes the empirical probe.

\section{Conclusion}

The present study examined competition in the South African manufacturing sector from the latest published statistics in the Stats SA Compendium of Industrial Statistics. It is found that there is limited evidence to support the existence of domineering market power between and within industries. Instead the picture that emerges is one of market power being curtailed by competition in which enterprises engage in rivalry for market supply. They appear to do so by means of:

(a) Allocative efficiency to find the markets where they should operate if rates of return from existing operations are unpromising;

(b) Productive efficiency reflected in economies of scale and absolute cost advantages to secure not only cost effective ways to production but also to ensure that such production is not easily replicated by rivals; and

(c) Innovating through the introduction of products, production processes, and operational structures that seek to make both aforementioned types of efficiencies possible.

The empirical results of the study show that competition impacts different market environments differently. Where the market environment makes it less likely for allocative efficiency, productive efficiency, and innovation to emerge, rivalry becomes less likely and vice versa. Consequentially any negativity from industry or market concentration to its linkages with output, employment, labour productivity, profit margins, rates of return, investment, and producer prices, has more to do with the limiting of rivalry between enterprises, as opposed to high industrial concentration by itself promoting poor economic performance. This is the central message of the current empirical probe.

It should be kept in mind that the findings are not in isolation. For instance, using Stats SA data on the South African manufacturing sector, Leach (1992: 151-152; 1997: 18-22) twice found the prevalence of the same competitive picture in this sector. Thus the contribution of the present study, as well as these past studies, is to contextually the understanding of industrial concentration in the South African manufacturing sector. The studies are consistent in 
showing that according to official statistics the high level of concentration in this sector is not linked to firm conduct that is absent of competition. Instead they fit closely with Alchian's (1950: 218) seminal description of market rivalry where:

"The pursuit of profits ... is the relevant objective whose fulfilment is rewarded with survival. Unfortunately, even this proximate objective is too high. Neither perfect knowledge of the past nor complete awareness of the current state ... gives sufficient foresight to indicate profitable action. ... The pervasive effects of uncertainty prevent ... actions which are supposed to be optimal in achieving profits."

As a result, adaptive behaviour by enterprises through imitation or experimental (i.e. trial-and-error) actions while being very likely to lead to positive profitability is poised to bring a market environment where profit margins and rates of return are determined by how successful or decisive they are at innovating if they wish to grow their output, raise labour productivity, invest and employ more, and also secure the demand-inducing prices commensurate with their innovative record.

\section{References}

Alchian, A. 1950. 'Uncertainty, evolution, and economic theory', Journal of Political Economy, 58(3):211-221.

Andreosso, B. \& Jacobson, D. 2005. Industrial economics and organization: A European perspective. $2^{\text {nd }}$ ed. Berkshire: McGawHill Education.

Cabral, L. 2000. Introduction to industrial organization. Cambridge: MIT Press.

Everitt, B. \& Dunn, G. 1982. An introduction to mathematical taxonomy. Cambridge: Cambridge University Press.

Ertl, H. \& McCarrell, H. 2002. 'The state of telecommunications services', Connectedness Series, Ottawa: Statistics Canada.

Fagerberg, J. 2009. A guide to Schumpeter. In: Ostreng, W. (Ed.). Confluence: interdisciplinary communications 2007/2008. Oslo: Centre for Advanced Study.

Fedderke, J. \& Simbanegavi, W. 2008. 'South African manufacturing industry structure and its implications for competition policy', Journal of Development Perspectives, 4(1):134-189.

Khemani, R. \& Shapiro, D. (Eds.). 1993. Glossary of industrial organisation economics and competition law. Paris: Organisation for Economic Co-operation and Development.

Kornai, J. 1980. 'The dilemmas of a socialist economy: The Hungarian experience', Cambridge Journal of Economics, 4(2):147-157.

Leach, D. 1992. 'Concentration and profits in South Africa: Monopoly or efficiency?', South African Journal of Economics, 60(2):143-157.
Lachmann, L. 1992. 'Socialism and the market: A theme of economic sociology viewed from a Weberian perspective', South African Journal of Economics, 60(1):24-43.

Leach, D. 1992. 'Concentration and profits in South Africa: monopoly or efficiency?', South African Journal of Economics, 60(2):143-157.

Leach, D. 1997. 'Concentration-profits monopoly vs. efficiency debate: South African evidence', Contemporary Economic Policy, 15(2):12-23.

Martins, J. \& Price, T. 2004. 'How market imperfections and trade barriers shape specialization: South America vs. OECD', Economics Department Papers. Paris: Organisation for Economic Co-operation and Development.

Reekie, W. 1989. Industrial economics: A critical introduction to corporate enterprise in Europe and America. Aldershot: Edward Elgar Publishing.

Reekie, W. 1991. Issues in industrial economics. Johannesburg: Witwatersrand University Press.

Salvatore, D. 1982. Theory and problems of statistics and econometrics. New York: McGraw-Hill, Inc.

Stats SA. 2012. Compendium of industrial statistics, 2012. Pretoria: Statistics South Africa.

Stigler, G. 1957. 'Perfect competition, historically contemplated', Journal of Political Economy, 65(1):1-17.

Stigler, G. 1964. 'Competition and concentration', Challenge, 12(4):18-21.

Tirole, J. 1998. The theory of industrial organisation. Cambridge: MIT Press.

West, J. 2007. 'Competition and barriers to entry', Policy Brief. Paris: Organization for Economic Co-operation and Development. 
